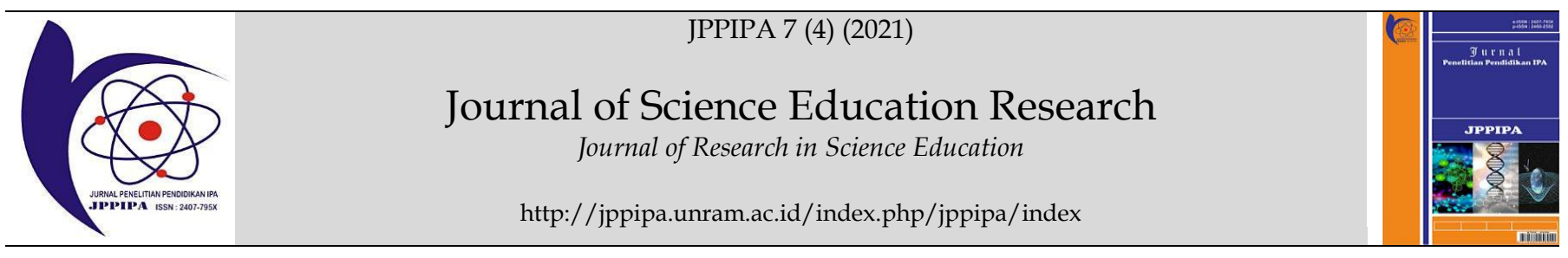

\title{
Relationship between Learning Motivation and Biology Learning Outcomes
}

\author{
Nurul Aulia Rahmi 1* ${ }^{*}$, Ramadhan Sumarmin'1, Yuni Ahda ${ }^{1}$, Heffi Alberida1 ${ }^{1}$ Abdul Razak1 \\ ${ }^{1}$ Biology Department, Master's Degree Program of Biology Education, Universitas Negeri Padang, Padang, Indonesia
}

DOI: $\underline{10.29303 / \text { ippipa.v7i4.773 }}$

\section{Article Info}

Received: May 31'st, 2021

Revised: September 15th, 2021

Accepted: September 22nd, 2021

\begin{abstract}
This research is a descriptive correlation study that aims to reveal the relationship between learning motivation and learning outcomes of students' biology. This study uses a correlational study approach because it connects two variables, namely two independent variables in the form of learning motivation and the dependent variable in the form of biology learning outcomes of students. The technique used in sampling is purposive proportional random sampling, by determining the proportion according to the number of students in the school being studied. In this study, Pearson Product Moment using for conversion score analysis, score distribution, normality tests, and correlation analysis. This correlation analysis aims to determine the relationship between learning motivation and learning outcomes of biology. Furthermore, to see whether or not there is meaning in the research, the t-test is used and to see the contribution between the two variables using the coefficient determinant formula. The results show that there is a positive and meaningful relationship between learning motivation and learning outcomes of students in class $X$ MIPA SMAN in Padang City with the value of $t_{\text {count }}$ are 7.603, at the level of confidence $95 \%$ with $\mathrm{db}=285$, greater than $t_{\text {table }}$ which is 1.650 .
\end{abstract}

Keywords: Learning Motivation; Learning Outcomes; Biology.

Citation: Rahmi, N., Sumarmin, R., Ahda, Y., Alberida, H., \& Razak, A. (2021). Relationship between Learning Motivation and Biology Learning Outcomes. Jurnal Penelitian Pendidikan IPA, 7(4), 537-541. doi:https://doi.org/10.29303/jppipa.v7i4.773

\section{Introduction}

Education is one of the assets for a person to be successful and be able to achieve success in life. The educational process is an effort to develop the potential of students to the maximum according to their talents and interests, both formally and informally. Students get knowledge from various kinds of things they learn in school. Teachers have an important role in improving the quality of education. As good educators, teachers have in-depth knowledge and understanding of the material to be taught. The teacher seems to be able to develop the curriculum if the teacher is able to make a syllabus that is in accordance with the curriculum and can make plans to carry out learning according to students to achieve learning objectives
(Kartini et al., (2019). Students who have high achievements have good knowledge.

The problem that is often faced in the learning process is the low learning outcomes obtained by students. Many factors influence the success of a person in learning, influence it is motivation. According to Harahap et al. (2021), motivation serves as a driver of effort in achieving achievements because a person doing business must encourage his desire and determine the direction of his actions towards the goal to be achieved. Thus students can select actions to determine what to do that serves the goals they want to achieve. Learning outcomes will be optimal if accompanied by motivation at denvy. The more precise the motivation is given, the more successful the learning will be. Students who have inner motivation to 
learn will become more diligent, work hard, be diligent, active, and fully concentrate on learning activities. According to Cahyani et al. (2020), Learning motivation is the overall driving force that lies in learners who give rise to the intention to do learning activities so that the desired goal is achieved. Ilyas et al. (2020) state that learning motivation is a power within students that encourages them to study diligently, make the best efforts, and be directed in the learning process to achieve the best results is a goal that is owned and maintained during the learning process. The factors that influence students' learning achievement include students' intellectual abilities, students' learning styles, and students' learning motivation.

At the time of learning, students will be successful if there is a willingness to learn and a desire or encouragement to learn, because, with an increase in learning motivation, students will be moved, directed to their attitudes and behavior to learn. Students who have high motivation for education tend to be involved in all learning activities, focus, and are diligent during the learning process. Many factors can affect motivation to learn. According to Lagili et al. (2019), learning motivation can arise due to internal and external factors. Internal factors that affect learning motivation are ideals and aspirations that are able to provide spirit, a clear goal in one's success. External factors include conducive learning environment conditions success in learning is also influenced by the facilities and infrastructure in the school.

Success in learning is also influenced by the existing facilities and infrastructure at school (Palittin et al., 2019). Schools that have complete and adequate facilities and infrastructure increasingly motivate students to learn to get good learning outcomes. According to Abdullah et al. (2021), students who have high learning motivation will find it easier to understand learning, but if the motivation is low, students look unenthusiastic, so they have difficulty understanding the concepts and learning process. Low learning motivation will result in sub-optimal learning outcomes. An important task for teachers is to plan how they will support the motivation of students. According to Fauziah et al. (2017), motivation is one factor that is very important to encourage the spirit of learning students. In motivation, there are also strong desires and ambitions. So that students who have learning motivation will understand what the goal of learning is. In addition, the good condition of students in learning will cause the student to be passionate about learning and able to complete the task well. Therefore, students' interest and motivation to learn must always be grown because failure in learning is caused by students and perhaps by teachers who fail to grow students' learning motivation so that student's interest in learning decreases and their enthusiasm for learning becomes less. A teacher is required to be able to act as an important motivator in increasing the enthusiasm and development of student learning activities.

Based on observations that have been made in several public high schools in the city of Padang, it is known that students in class $\mathrm{X}$ MIPA have low motivation. This is known from students' learning outcomes who are still under the specified minimum completeness criteria (MCC). Students still lack preparation for learning, such as not doing their own assignments and being lazy to pay attention to the teacher while teaching. Because motivation is one of the factors that cause low learning outcomes, researchers are interested in examining the relationship between learning motivation and learning outcomes of students in class X MIPA Public Senior High Schools in Padang City.

\section{Method}

This research is a descriptive correlation study that aims to reveal the relationship between learning motivation and student learning outcomes. This study uses a correlational study approach because it connects two variables, namely two independent variables in the form of learning motivation and the dependent variable in the form of student learning outcomes. The technique used in sampling is purposive proportional random sampling, by determining the proportion according to the number of students in the school being studied. In this study, the researchers took samples that met $30 \%$ of the study population and were taken in a random way. The population in this study was all public high schools in Padang, which consisted of 16 schools totaling 1021 students. The sample in this study amounted to 287 students who were randomly distributed to 5 schools.

The variables in this study consisted of the independent variable $(X)$ and the dependent variable $(\mathrm{Y})$. The independent variable is students' learning motivation, and the dependent variable is students' cognitive biology learning outcomes. The instrument in this study used a valid questionnaire and a number of statements with a total of 20 items of learning motivation questionnaire and 40 multiple-choice questions.

In this study, Pearson Product Moment using for conversion score analysis, score distribution, normality tests, and correlation analysis. This correlation analysis aims to determine the relationship between learning motivation and learning outcomes. Furthermore, to see 
whether there is meaning in the study, the t-test is used to see the contribution between the two variables using the coefficient determinant formula. The learning motivation questionnaire uses a Likert scale.

\section{Result and Discussion}

Based on the research that has been done, the following results are obtained.

Table 1. Data on Learning Motivation Scores and Learning Outcomes of Students

\begin{tabular}{lllll}
\hline \multirow{2}{*}{ Respondents } & \multicolumn{2}{l}{ Score } & & \\
\cline { 2 - 5 } & \multicolumn{2}{l}{ Learning Motivation } & \multicolumn{2}{l}{ Learning Outcomes } \\
\cline { 2 - 5 } & Highest & Lowest & Highest & Lowest \\
\hline 287 & 76 & 44 & 82.5 & 20 \\
Average score & 62.14 & & 47.2 & \\
\hline
\end{tabular}

The results of descriptive analysis of the student learning motivation questionnaire show that overall, the learning motivation of students of class X MIPA SMAN in Padang City in biology is quite sufficient, namely in the range of $65-79 \%$, while the learning outcomes of biology are still classified as lacking because the average learning outcomes of students are still below the specified MCC. A child who is motivated to learn something will try to learn it well and diligently, with the hope of getting good results. In that case, it appears that the motivation to learn causes a person to study hard. On the other hand, if a person lacks or does not have the motivation to learn, then they cannot stay long in learning. They is easily tempted to do other things and not study. That means motivation is very influential on resilience and persistence in learning. Furthermore, to determine the analysis of the relationship between learning motivation and learning outcomes, it can be seen in the following table.

Table 2. Data on the Analysis of the Relationship between Learning Motivation and Learning Outcomes.

\begin{tabular}{|c|c|c|c|c|}
\hline \multirow[t]{2}{*}{ No } & \multirow[t]{2}{*}{ Parameter } & \multicolumn{2}{|l|}{ Variable } & \multirow[t]{2}{*}{ Information } \\
\hline & & $X$ & $Y$ & \\
\hline \multirow[t]{2}{*}{1.} & Normality & $\mathrm{L}_{0}=0.044$ & $\mathrm{~L}_{0}=0.049$ & $\mathrm{~L}_{0}<\mathrm{L}_{\mathrm{t}}$ \\
\hline & Test & $\mathrm{L}_{\mathrm{t}}=0.052$ & $\mathrm{~L}_{\mathrm{t}}=0.052$ & $\begin{array}{l}\text { Normally } \\
\text { Distributed }\end{array}$ \\
\hline 2. & $\begin{array}{l}\text { Correlation } \\
\text { analysis }\end{array}$ & $\mathrm{r}=0.410$ & & $\begin{array}{l}\text { Medium } \\
\text { correlation }\end{array}$ \\
\hline 3. & $\mathrm{t}$ test & $\begin{array}{l}\mathrm{t}_{\mathrm{count}}=7.603 \\
\mathrm{t}_{\text {table }}=1.650\end{array}$ & & $\begin{array}{l}t_{\text {count }}>t_{\text {table }} \\
\text { Means }\end{array}$ \\
\hline
\end{tabular}

Based on the table above, the normality test on variables $\mathrm{X}$ and $\mathrm{Y}$ show $\mathrm{L}_{0}<\mathrm{L}_{\mathrm{t}}$ means that the data is normally distributed. The results of the correlation analysis using Pearson Product Moment showed that the relationship between the $\mathrm{X}$ and $\mathrm{Y}$ variables was a moderate or sufficient correlation with a value of $r=$
0.4106 because there are many other factors that can affect learning outcomes, such as family factors, environment, learning styles, and others. Another factor is the lack of instructional media provided by the teacher. Students are more active in learning when given a variety of media.

Furthermore, for the t-test, the results obtained $t_{\text {count }}>t_{\text {table }}$ meaning that there is a significant correlation between variables X and Y. Warti (2018) states that there is a positive relationship between learning motivation and learning outcomes. Therefore, in learning, motivation is needed for students so that students can achieve satisfactory learning achievements. Then to see the size of the contribution of the value of learning motivation on learning outcomes is determined by the formula of the coefficient of determination (CD), the value of $C D=$ $16.863 \%$, meaning that the influence of variable $X$ on variable $\mathrm{Y}$ is $16.863 \%$, while other factors influence the rest.

Based on the data analysis that the researcher has conducted, the results show that the learning motivation of students of class X MIPA SMAN in Padang City, which is spread over five schools in biology subjects, is included in the sufficient category. This is evidenced by the average score of the student learning motivation questionnaire is 62.14. According to Sari et al. (2018), their research shows that the average learning motivation of students is in the medium and low categories due to the lack of interest in students to learn. In addition, external factors influence is the learning environment of students. An active learning environment can foster motivation to learn.

The analysis of learning motivation in each school, namely SMAN 7, SMAN 8, SMAN 12, SMAN 14 , and SMAN 15, was sufficient. This is evidenced by the average score of the student learning motivation questionnaire in the range 59.35-64.31. Students who are motivated to learn will be active and have high curiosity about certain subjects. In addition, external factors influence is the learning environment of students. An active learning environment can foster motivation to learn. The teacher can create an active learning environment through the implementation of learning. If someone has a strong and high motivation to learn, the learning outcomes obtained in biology will increase. In learning and teaching activities, motivation is needed. Without motivation, learning will be in vain because of a lack of internal encouragement to learn (Awe et al., 2017). According to Mustafa et al. (2018), the learning success of students is determined by their learning motivation. This can be observed from the acquisition of the final score after learning. Generally, 
students get high scores because of their high motivation to learn. If not, students get low scores because of low learning motivation.

Taurina (2015) states that different factors influence students' motivation. The following factors should be considered significant: the positive environment, linkages, and perceptions of teachers and others. Taking into account these factors and their impact, one should strive to avoid unfavorable factors and develop positive ones to help learners achieve learning outcomes in the best possible way. Therefore, motivation is a very important factor in the learning process so that students are more active in learning. Students who feel motivated will be very happy to learn even in doing the given assignments. According to Bahri et al. (2015), learning strategies do not need to be focused on cognitive learning outcomes alone but must also be able to increase students 'motivation and learning motivation to activate students' metacognition, both of which are important predictors of learning. Motivation to learn is a mediator between stimulation and reaction. In other words, learning motivation is the opinion of students about individual problems and requires the acquisition of knowledge because of differences in opinion of each individual (Lin et al., 2017).

Motivation has a big role in one's success in learning. In the development of motivation, many factors affect it, including: (1) Student Ideals and Aspirations, (2) The Skills Students Have, (3) The Physical and Spiritual Condition of Students, (4) The Environmental Condition of students, (5) Dynamic Elements in Learning, (6) Effort or Encouragement of Teachers in Motivating. So if someone has great motivation to learn, then he has a great desire to succeed (Saputra et al., 2018). Andriani and Rasto (2019), Learning motivation reflected in indicators of activity duration, frequency of activities, presence, devotion, and sacrifice, fortitude, tenacity and ability, level of inspiration, level of qualifying results, and direction of attitude towards the target of the activity has an important role in student learning outcomes. This means that if students are motivated to learn, their learning achievement will be good (high). Conversely, if students have bad habits in learning, their learning achievement will be bad (low).

According to Bahri et al. (2015), learning motivation is mental strength in a person's life that triggers learning activities, ensures continuity of learning, and provides direction for learning activities in an orderly manner to achieve goals. Motivation to learn involves learning goals and strategies related to achieving learning goals. Alhadi and Nanda (2017) conclude that a clear picture is that learning motivation is an important aspect of achieving student learning outcomes. Students who have great motivation to learn will show interest, attention, concentration, persistence and are process-oriented and learning outcomes. Conversely, students who do not have the motivation to learn will show boredom, easily give up, and try to avoid learning activities. Students who have high learning motivation in learning biology show interest and interest in learning so that the learning outcomes obtained are also high. According to Arguedas et al. (2016), there is a significant positive correlation between emotional awareness and motivation and the involvement of students in learning as when students feel sad. They can receive and constructively provide suggestions and opinions succeed in maintaining their involvement during the activity. Therefore, in learning, motivation is needed for students so that students can achieve satisfactory learning achievements. The higher the motivation that is in him, the higher the achievements he will achieve. If a person already has great motivation to learn, he will be active and always try to get maximum results.

\section{Conclusion}

Based on the results of the study concluded that there is a positive and meaningful relationship between learning motivation and the learning outcomes of biology students class X MIPA SMAN in Padang City with a value of $t$ of 7,603 at a confidence level of $95 \%$ with $\mathrm{db}=285$, greater than the $t_{\text {table }}$ of 1,650 . The relationship of learning motivation with the biology learning outcomes of class X MIPA students in SMA Negeri in Padang is in the sufficient category.

\section{Acknowledgments}

Researcher thanks the supervisor who has guided in making this research article, then the researcher also thanks the biology subject teacher at the Public High School in the city of Padang, who has given permission to conduct research at school, and the researcher also thanks Biology Education PPS Study Program, FMIPA UNP which has facilitated this research.

\section{References}

Abdullah, N., Khaldun, I., \& Musman, M. (2021). The Influence of Pocketbook to Improve Student Learning Outcomes and Motivation on Electron Configuration Material. Jurnal Penelitian Pendidikan IPA, 7(3), $298 . \quad$ doi: https://doi.org/10.29303/jppipa.v7i3.647 
Alhadi, S., \& Saputra, W. N. E. (2017). The Relationship between Learning Motivation and Learning Outcome of Junior High School Students in Yogyakarta BT - Proceedings of the 1st Yogyakarta International Conference on Educational Management/Administration and Pedagogy (YICEMAP 2017). 138-141. https://doi.org/https://doi.org/10.2991/yicem ap-17.2017.23

Andriani, R., \& Rasto. (2019). Motivasi Belajar Sebagai Determinan Hasil Belajar Siswa. Jurnal Pendidikan Manajemen Perkantoran. 4 (1), 80-86. doi: https://doi.org/10.17509/jpm.v4i1.14958 [Indonesian]

Arguedas, M., Daradoumis, T., \& Xhafa, F. (2016). Analyzing how emotion awareness influences students' motivation, engagement, selfregulation and learning outcome. Educational Technology and Society, 19( 2), 87-103. Retrieved from: https:/ / eric.ed.gov/?id=EJ1097275

Awe, E. Y., \& Benge, K. (2017). Hubungan Antara Minat Dan Motivasi Belajar Dengan Hasil Belajar Ipa Pada Siswa Sd. Journal of Education Technology, 1(4), 231. https://doi.org/10.23887/jet.v1i4.12859 [Indonesian]

Bahri, A., \& Corebima Aloysius, D. (2015). The contribution of learning motivation and metacognitive skill on cognitive learning outcome of students within different learning strategies. Journal of Baltic Science Education, 14, 487-500.

https://doi.org/10.33225/ibse/15.14.487.

Cahyani, A., Listiana, I. D., \& Larasati, S. P. D. (2020). Motivasi Belajar Siswa SMA pada Pembelajaran Daring di Masa Pandemi Covid-19. IQ (Ilmu Alqur'an): Jurnal Pendidikan Islam, 3(01), 123-140. https://doi.org/10.37542/iq.v3i01.57 [Indonesian]

Fauziah, A., Rosnaningsih, A., \& Azhar, S. (2017). Hubungan Antara Motivasi Belajar dengan Minat Belajar Siswa Kelas IV SDN Poris Gaga 05 Kota Tanggerang. Jurnal JPSD (Jurnal Pendidikan Sekolah Dasar), 4(2), 47-53. doi:http://dx.doi.org/10.12928/jpsd.v4i2.9594 [Indonesian]

Harahap, N.F., Anjani, D., \&Sabrina, N. (2021). Analisis Artikel Metode Motivasi dan Fungsi Motivasi Belajar Siswa. IJI Publication. 1 (3). 198-202. DOI: https://doi.org/10.51577/ijipublication.v1i3.121

Ilyas, I., \& Liu, A. N. A. M. (2020). The Effect of Based E-learning Contextual Approach on Student Learning Motivation. Jurnal Penelitian Pendidikan
IPA, 6(2), $184 . \quad$ doi: https://doi.org/10.29303/jppipa.v6i2.425

Kartini, K., Doyan, A., Kosim, K., Susilawati, S., Khasanah, B. U., Hakim, S., \& Muliyadi, L. (2019). Analysis of Validation Development Learning Model Attainment Concept to Improve Critical Thinking Skills and Student Learning Outcomes. Jurnal Penelitian Pendidikan IPA, 5(2), 185. doi: https:// doi.org/10.29303/jppipa.v5i2.262

Lagili, I.L., Moonti, U., \& Mahmud, M. (2019). Identifikasi Faktor-Faktor yang Mempengaruhi Motivasi Belajar Mahasiswa Pada Program Studi S1 Pendidikan Ekonomi Angkatan 2015 Fakultas Ekonomi Universitas Negeri Gorontalo. Ekonomic Education Journal, 2 (1), 15-29. doi: https://doi.org/10.37479/jeej.v1i1.2082

[Indonesian]

Lin, M. H., Chen, H. C., \& Liu, K. S. (2017). A study of the effects of digital learning on learning motivation and learning outcome. Eurasia Journal of Mathematics, Science and Technology Education, 13(7), 3553-3564. doi: https://doi.org/10.12973/eurasia.2017.00744a

Mustafa, M. N., Hermandra, H., Zulhafizh, Z., \& Hermita, N. (2018). The Significance of Language Motivation Learning: Correlation Analysis. Advanced Science Letters, 24(11), 8380-8383. doi: https://doi.org/10.1166/asl.2018.12568

Palittin, I. D., Wolo, W., \& Purwanty, R. (2019). Hubungan Motivasi Belajar Dengan Hasil Belajar Fisika. MAGISTRA: Jurnal Keguruan Dan Ilmu Pendidikan, 6(2), 101-109. doi: https://doi.org/10.35724/magistra.v6i2.1801 [Indonesian]

Saputra, H., Ismet, F., \& Andrizal, A. (2018). Pengaruh Motivasi Terhadap Hasil Belajar Siswa SMK. INVOTEK: Jurnal Inovasi Vokasional Dan Teknologi, 18(1), 25-30. https://doi.org/https://doi.org/10.24036/invot ek.v18i1.168 [Indonesian]

Taurina, Z. (2015). Students Motivation and Learning Outcomes: Significant Factors in Internal Study Quality Assurance Aystem. International Journal for Cross-Disciplinary Subjects in Education (IJCDSE), 5(4), 2625-2630. Retrieved from https://infonomics-society.org/...System.pdf

Warti, E. (2018). Pengaruh Motivasi Belajar Siswa terhadap Hasil Belajar Matematika Siswa di SD Angkasa 10 Halim Perdana Kusuma Jakarta Timur. Mosharafa: Jurnal Pendidikan Matematika, 5(2), 177-185. doi: https://doi.org/10.31980/mosharafa.v5i2.273 [Indonesian] 